\title{
Movement patterns of the spiny lobster Palinurus elephas (Fabricius, 1787) from a central western Mediterranean protected area
}

\author{
MARIA CRISTINA FOLLESA, DANILA CUCCU, RITA CANNAS, ANDREA SABATINI, \\ ANNA MARIA DEIANA and ANGELO CAU \\ Department of Animal Biology and Ecology, University of Cagliari, Viale Poetto, 1- 09126 Cagliari, Italy. \\ E-mail: follesac@unica.it
}

\begin{abstract}
SUMMARY: Movement patterns of the spiny lobster Palinurus elephas were determined from 389 individuals (total tagged 5666) tag-recaptured inside a no-take area of the central western Mediterranean and its surrounding zone. High site association and limited movements in tagged lobsters was observed; $60.4 \%$ of lobsters moved less than $2 \mathrm{~km}$ from the centre of the area (site of release). No clear relationship between lobster movement pattern and sex or size was observed; however, it seemed that the largest males and females tended to be more resident, thus contributing to the rebuilding of the biomass of local lobsters. Most lobsters undertook migrations in the southwest direction. The increased availability of shelters and food towards the southwest could have contributed to the lobsters' movement. The results of our research indicate that the small size of the protected area and the scale of the movement exhibited by tagged lobsters allows a proportion of the lobster population to move out of the protected area and become susceptible to capture in the adjacent fishery.
\end{abstract}

Keywords: lobster, Palinurus elephas, protected area, spillover, movement.

RESUMEN: Pautas de movimiento de la langosta PalinuRus elephas (Fabricius, i787) desde un área Protegida en el Mediterráneo occidental central. - Se determinaron las pautas de movimiento de 389 individuos de la langosta Palinurus elephas (total marcados 5666) marcados y recapturados en el interior de un área protegida (sin captura) así como de su área circundante. En las langostas marcadas se observó una elevada asociación al lugar de liberación, así como movimientos limitados: el $60.4 \%$ de las langostas se movieron menos de $2 \mathrm{~km}$ desde el centro del área de liberación. No se observó ninguna clara relación entre las pautas de movimiento de las langostas y su sexo y talla; no obstante, hay una tendencia a que los machos y hembras grandes muestren un comportamiento más residente, contribuyendo así al aumento de la biomasa local. La mayor parte de langostas mostró migraciones en dirección sudoeste. La mayor disponibilidad de refugios y alimento hacia el sudoeste pudo haber contribuído al movimiento de las langostas. Los resultados de este estudio indican que el pequeño tamaño del área protegida y la escala de movimientos mostrados por las langostas marcadas permite a una porción de la población su salida del área protegida y su susceptibilidad a la captura en la pesquería adyacente.

Palabras clave: langosta, Palinurus elephas, área protegida, excedente, movimiento.

\section{INTRODUCTION}

The effect of a reduction in fishing effort on the density and biomass of lobster populations has been thoroughly investigated in the Mediterranean Sea and in other marine regions (Sanchez Lizaso et al., 2000). Most studies conclude that fishery reserves can increase lobster stocks in neighbouring areas, particularly through the migration of adults (Dugan and Davis, 1993; Roberts and Polunin, 1993; Rakitin and Kramer, 1996; Rowe, 2001; Guenette et al., 1998; Kelly et al., 2002; McGarvey, 2004; Follesa et al., 2007). However, there are few studies detailing lobster emigration from protected areas. General 
aspects of ecology and behaviour, such as type of movement, site fidelity and habitat selection, have been poorly investigated even though there has been a considerable increase in research on spiny lobsters in the last two decades (Phillips and Kittaka, 2000; Goñi and Latrouite, 2005).

Movement patterns of lobsters play an important role in determining a population's response to marine reserves (Polacheck, 1990; DeMartini, 1993; Attwood and Bennett, 1995; Guenette and Pitcher, 1999). Patterns of lobster movement can be divided into three general categories (Herrnkind, 1980): migrations, wherein an individual or population moves a considerable distance, often but not always returning to the original area; nomadism, the wandering of individuals without any clear start and end points; and homing, the periodic, often daily, excursions from a shelter to some nearby area, with subsequent return to that shelter or others nearby. Each of these patterns is thought to be developed from some biological need such as food, shelter, reproduction or recruitment, and different lobster species may exhibit any, or all, of these patterns during their life histories (Stewart and Kennelly, 1998).

Movement patterns have been studied in many migratory spiny lobsters, including Panulirus argus (Latreille, 1804), P. cygnus, George, 1962, P. ornatus (Fabricius, 1798), P. guttatus (Latreille, 1804) and Jasus edwardsii (Hutton, 1875) (review in Herrnkind, 1983). All these species exhibit nomadic movements spanning several kilometres, as well as seasonal mass migrations of up to $500 \mathrm{~km}$ (Herrnkind, 1983). The neurohormonal mechanisms and environmental factors orienting these movements remain unknown. Although several aspects of the biology of $P$. elephas (Fabricius, 1787) have been investigated, knowledge of the movements of this species is still very poor. Most previous studies have been on observations of individuals in situ or held in captivity (Mercer, 1973; Hunter et al.,1996; Díaz et $a l ., 2001$ ) and have highlighted nocturnal habits and movements related to foraging, reproduction and shelter use (Goñi and Latrouite, 2005; Giacalone et al., 2006).

The aim of this paper is to further investigate the movement patterns of $P$. elephas in a protected area and the surrounding commercial zones in the central-western Mediterranean by means of a tag-recapture programme carried out from 1997 to 2007. Movement was analyzed in relation to the lobster's size and sex.

\section{MATERIALS AND METHODS}

The study was carried out in a protected area (called the "Su pallosu area") of central-western Sardinia in the central-western Mediterranean Sea, at 50-100 m depth and in the surrounding fishery zone (the zone around the protected area, mainly within a radius of $<5 \mathrm{~km}$ from the centre of the area).

The protected area, first identified in 1997, was chosen as a point of release on account of its geomorphological and bionomic characteristics. When investigated by scuba divers, it proved to be characterised by formations comparable to coastal precoralligenous and coralligenous detritus (Pérès and Picard, 1964). Since 1998, fishing has been prohibited in the ca. $4 \mathrm{~km}^{2}$ area (Regional Law No. 776 of 6-5-1998) (Secci et al., 1999). From 1998 to 2007 (except for 2002 and 2003), a total of 5666 individuals [mean Carapace Length (CL) of 45.59 $\mathrm{mm} \pm 6.68 \mathrm{SD}$ for females $(\mathrm{N}=3141)$ and 46.01 \pm 8.45 SD for male $(\mathrm{N}=2525)$ ], from samples taken from the "Su pallosu area" $(\mathrm{N}=1898)$ and commercial captures made by local fishermen $(\mathrm{N}=$ 3768 ), were tagged and released inside the protected area. The plastic T-bar-type tags were inserted dorso-laterally between the first and second abdominal segments using a tagging gun (Campillo et $a l ., 1979)$. After about three days in tanks in order to assess tagging stress (estimated mortality of ca. $3 \%$, Secci et al., 1999), the tagged individuals were released mainly in the centre of the protected area. Data recorded upon initial tagging and subsequent recaptures included tag number location. When a lobster was recaptured, the identification number of the tag was recorded. Samples were recaptured during experimental samplings inside the area and commercial fishing in the surrounding fishery zone. Commercial captures in the zone surrounding the protected area were made primarily by the fishermen involved in experimental samplings within the no-take area. These fishermen all belonged to the $\mathrm{Su}$ Pallosu fishing cooperative. The fishing effort outside the protected area, made generally by fishermen of the cooperative, was evenly distributed around the area. The few fishermen not belonging to the $\mathrm{Su}$ pallosu cooperative were encouraged to return the tagged lobsters to the cooperative fishermen. In this way the lobsters could be released again in the centre of the protected area. This allowed longer-term movement information to be collected at subsequent recaptures. 
During the recapture programme, experimental sampling inside the "Su pallosu area" was conducted following a specific programme. Each year, in the period from May to September (when commercial fishing is allowed), an average of 10 experimental samplings were carried out (except for 2004, when there were only four). Sampling was conducted using trammel nets of $1000 \mathrm{~m}$ length (nominal mesh size from 50 to $73 \mathrm{~mm}$ ) following a sampling plan with transects set up in such a way as to survey the whole protected area. The first transect was placed from west to east in the centre of the area, with the remaining nine parallel to it at a distance of $c a .250$ $\mathrm{m}$ from each other. The nets were put down in the middle of the day and hauled up in the morning of the following day.

Because the lobsters were captured during commercial or experimental sampling with nets, it was more difficult to know the exact point of the original site of capture prior to being tagged. Only for 8 individuals was it possible to know the initial capture location and then to estimate the homing ability.

Distance moved by lobsters was calculated as the straight line between the point of the release (centre of the protected area) and the point of recapture. The recapture point was always considered the middle point of the sample net.

To determine whether lobster movement varied with size, lobsters were subdivided into three size categories (small, $\mathrm{CL}<80 \mathrm{~mm}$; medium, $80<\mathrm{CL}<110$ $\mathrm{mm}$ and large, $\mathrm{CL}>110 \mathrm{~mm}$ ). The analysis was performed by sex for all individuals and for each size category.

The circular distribution of the lobsters' heading was analysed with the Rayleigh test (Zar, 1996). The hypotheses are as follows:

$\mathrm{H}_{0}=$ the sampled population is uniformly distributed around a circle.

$\mathrm{H}_{1}=$ the population is not uniformly distributed.

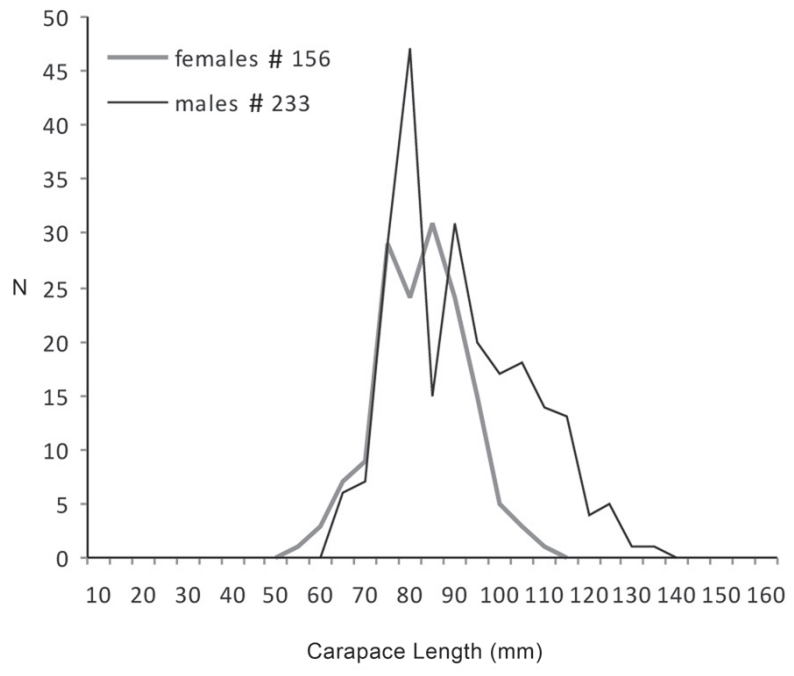

FIG. 1. - Size distribution (CL, mm) of tag-recaptured lobsters in the protected area and its surrounding zone.

If $\mathrm{H}_{0}$ is rejected we may conclude that there is a mean population direction, identified by a specified mean angle (Zar, 1996). The probability level of significant difference was set at $P=0.05$.

\section{RESULTS}

From 5666 tagged lobsters, a total of 389 (233 males, CL from 60.10 to $130.7 \mathrm{~mm}$ and 156 females, CL from 54.6 to $107.7 \mathrm{~mm}$ ) were recaptured both inside the protected area and in its surrounding fishery zone (Fig. 1). Of the total number, 323 lobsters were recaptured one time, 58 two, 7 three and 1 four times.

Although very few data of the initial capture location were available (only for 8 lobsters), no particular ability to orientate homeward was recorded. Only two female lobsters (respectively \# 4 and 7) were recaptured in the proximity of the initial point of capture (C, Fig. 2). Lobster \# 5 was recaptured in the opposite direction with respect to point $\mathrm{C}$,

TABLE 1. - Length increments, sex, days at liberty and movements [distance $(\mathrm{km})$ and direction] of eight lobsters tagged and release during the experimentation. $\mathrm{M}$, tagging; $\mathrm{RC}$, recapture; $\mathrm{C}$, point of initial site of capture; $\mathrm{RE}$, point of release; $\mathrm{RC}$, point of recapture.

\begin{tabular}{|c|c|c|c|c|c|c|c|c|c|c|}
\hline \multirow[t]{2}{*}{$\mathrm{N}^{\circ}$} & \multicolumn{2}{|c|}{ Carapace length (mm) } & \multirow[b]{2}{*}{ sex } & \multirow[t]{2}{*}{ Day at liberty } & \multicolumn{2}{|c|}{$\mathrm{C}-\mathrm{RC}$} & \multicolumn{2}{|c|}{$\mathrm{C}-\mathrm{RE}$} & \multicolumn{2}{|c|}{ RE-RC } \\
\hline & M & $\mathrm{RC}$ & & & distance & direction & distance & direction & distance & direction \\
\hline 1 & 75.00 & 83.60 & $\mathrm{~m}$ & 203 & 4.700 & $148^{\circ}$ & 0.160 & $118^{\circ}$ & 4.800 & $327^{\circ}$ \\
\hline 2 & 65.90 & 86.70 & $\mathrm{~m}$ & 942 & 0.521 & $164^{\circ}$ & 0.160 & $118^{\circ}$ & 0.642 & $334^{\circ}$ \\
\hline 3 & 54.00 & 61.00 & $\mathrm{f}$ & 262 & 4.400 & $44^{\circ}$ & 0.160 & $118^{\circ}$ & 4.500 & $226^{\circ}$ \\
\hline 4 & 89.00 & 91.90 & $\mathrm{f}$ & 399 & 0.102 & $335^{\circ}$ & 0.325 & $66^{\circ}$ & 0.339 & $229^{\circ}$ \\
\hline 5 & 99.30 & 99.00 & $\mathrm{~m}$ & 69 & 1.200 & $341^{\circ}$ & 0.727 & $153^{\circ}$ & 0.486 & $173^{\circ}$ \\
\hline 6 & 52.10 & 70.30 & $\mathrm{f}$ & 782 & 17.200 & $33^{\circ}$ & 0.453 & $349^{\circ}$ & 17.600 & $212^{\circ}$ \\
\hline 7 & 51.50 & 61.20 & $\mathrm{f}$ & 426 & 0.179 & $252^{\circ}$ & 0.574 & $14^{\circ}$ & 0.502 & $177^{\circ}$ \\
\hline 8 & 80.00 & 86.40 & $\mathrm{f}$ & 320 & 0.463 & $56^{\circ}$ & 0.459 & $324^{\circ}$ & 0.641 & $190^{\circ}$ \\
\hline
\end{tabular}




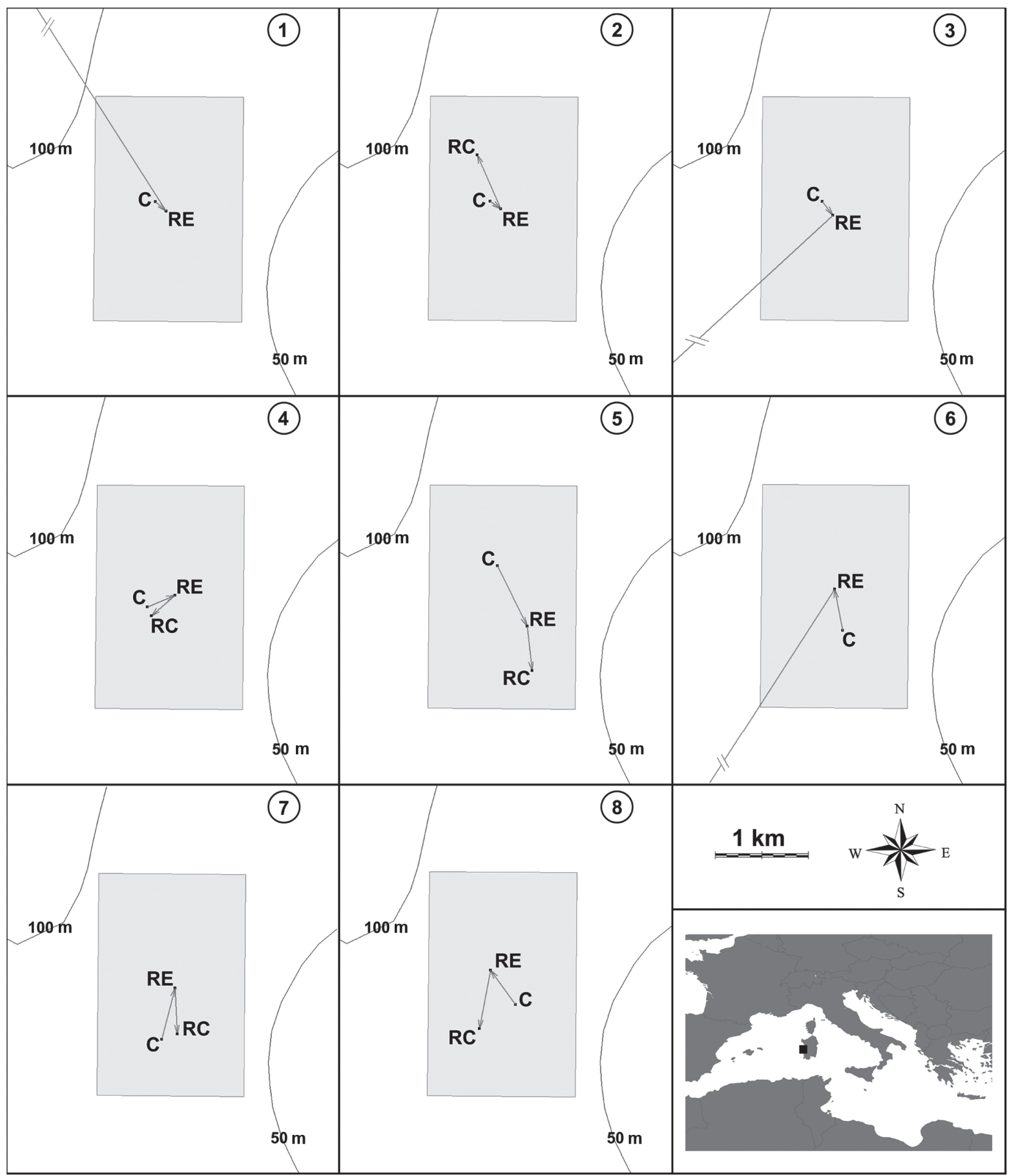

FIG. 2. - Movement patterns of the eight tagged lobsters inside and around the protected area (rectangular area). Legend: inside the circle the number of the tagged lobster; $\mathrm{C}$, point of initial site of capture; RE, point of release; $\mathrm{RC}$, point of recapture.

and lobsters (respectively \# 1-3-6) many kilometres away were found. No correlation was found between homing ability and sex or size (Table 1).

On the whole, strong site fidelity was evident in tagged P. elephas. As many as $60.4 \%$ of lobsters moved less than $2 \mathrm{~km}$ from the centre of the protected area (site of release). Moreover, $79.9 \%$ of lobsters were found at a distance of $<5 \mathrm{~km}$ from the centre; only $2.3 \%$ of the lobsters moved further than $20 \mathrm{~km}$. The greatest recorded movement was made 
TABLE 2. - Range of carapace length $(\mathrm{mm})$, mean distance travelled $(\mathrm{km})$ and mean of days at liberty of tagged and recaptured lobsters for different sex and size groups.

\begin{tabular}{|c|c|c|c|c|}
\hline & \multirow[b]{2}{*}{ Range CL (mm) } & \multicolumn{2}{|c|}{ Distance travelled $(\mathrm{km})$} & \multirow{2}{*}{$\begin{array}{c}\text { Days at liberty } \\
\text { mean }\end{array}$} \\
\hline & & mean & mean/year & \\
\hline total females & $54.6-107.7$ & $4.12 \pm 11.6$ & 2.62 & $573.2 \pm 465.7$ \\
\hline total males & $60.1-130.7$ & $3.15 \pm 5.89$ & 2.39 & $481.0 \pm 359.0$ \\
\hline $\begin{array}{l}\text { size groups } \\
\text { total small }\end{array}$ & & & & \\
\hline total small & $54.6-79.9$ & $2.18 \pm 3.28$ & 2.26 & $350.7 \pm 255.0$ \\
\hline small females & $57.0-79.9$ & $2.69 \pm 4.04$ & 2.58 & $380.3 \pm 272.7$ \\
\hline small males & $60.1-79.5$ & $1.91 \pm 2.56$ & 2.12 & $327.6 \pm 230.1$ \\
\hline total medium & $80.0-109.8$ & $3.94 \pm 6.14$ & 2.31 & $622.0 \pm 430.3$ \\
\hline medium females & $80.0-107.7$ & $3.66 \pm 5.30$ & 1.81 & $737.3 \pm 529.1$ \\
\hline medium males & $80.0-109.8$ & $4.12 \pm 6.69$ & 2.81 & $535.0 \pm 318.0$ \\
\hline large (only males) & $110.0-130.7$ & $1.30 \pm 2.44$ & 0.64 & $741.0 \pm 576.0$ \\
\hline
\end{tabular}

by an $80 \mathrm{~mm}$ CL female, which covered a distance of $134 \mathrm{~km}$ (in southeasterly direction) over a period of 712 days. The greatest distance moved by a male was $45.9 \mathrm{~km}$ southwest over 1546 days. On average, males apparently moved less than females $(3.15 \pm$ $5.89 \mathrm{~km}$ in a mean period of $481.0 \pm 359.0$ days versus $4.12 \pm 11.6 \mathrm{~km}$ in a mean period of $573.2 \pm 465.7$ days, respectively), although no statistical difference was observed between the two mean values $(t$ test $=$ $1.08646, P=0.278$ ) (Table 2). There was no significant relationship between time at large and distance moved (Table 2, Fig. 3). Linear regression analysis of the log-transformed data confirmed this statement (for females $\mathrm{y}=0.0002 \mathrm{x}-0.0065, r^{2}=0.017$; for males $y=0.000 x-0.008, r^{2}=0.040$ ).

Both males and females showed a low dispersion of the angles ( $r$ value of 0.134 and 0.176 respectively) which were not uniformly distributed around the circle (for males Rayleigh's test $z=4.2168, \mathrm{~N}=233$, $0.02<P<0.01$ and, for females $z=4.8451 \mathrm{~N}=156$, $0.01<P<0.005$ ) (Table 2). Direction of travel for males was $224.58^{\circ} \pm 75.36$ and for females $207.71^{\circ} \pm$ 73.54. Movement of both sexes tended to be mainly in a south-west direction (Fig. 4).

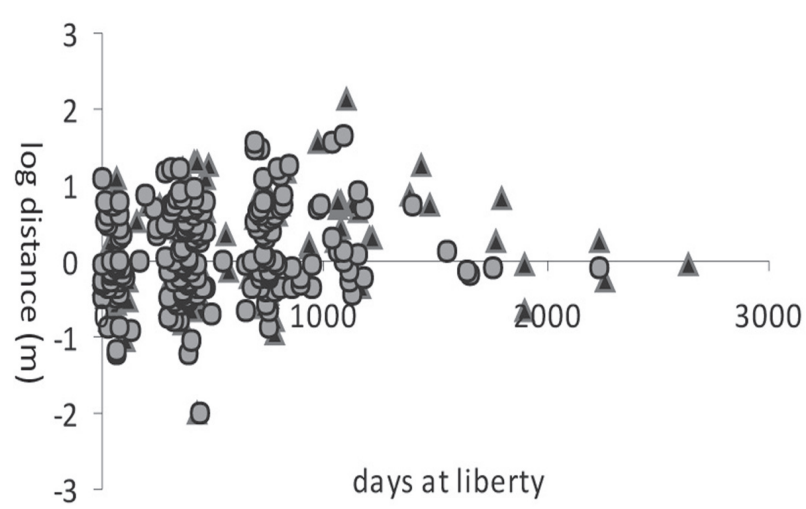

FIG. 3. - Relationship between days at liberty and distance travelled by males (circles) and females (triangles).
Of the three size groups, we observed males and females in the small and medium size groups. The largest females (CL 80.0- $107.7 \mathrm{~mm}$ ) observed were in the medium size group. In the large size group (110.0-130.7 $\mathrm{mm}$ ), only males were observed (Table 2).

From the analysis of the mean distance moved by various size groups, individuals of the large size group (males) travelled the lowest mean distance $(1.33 \pm 2.44 \mathrm{~km})$ (Table 2), highlighting a high site fidelity to the reserve in comparison with the other size groups. Significant differences in the mean distance travelled were found between the large and medium groups ( $t$ test $=-3.2346, P=0.0013)$ and large and small groups $(t$ test $=-2.0993 P=0.037)$. From the Rayleigh's test, the large group size highlighted a uniform distribution of the angles $(z=2.020, \mathrm{~N}$ $=25, P>0.1)$. The same pattern of distribution was also observed for female lobsters of the medium size group (the largest ones) $(z=0.9879, \mathrm{~N}=81$, $P>0.2$ ) (Table 3). Small females and males showed no uniform circular distribution and instead, a movement preferentially towards a southwest direction $\left(197.72^{\circ} \pm 69.73\right.$ and $267.68^{\circ} \pm 70.76$, respectively $)$. Medium-size males moved mostly in a south-east direction $\left(169.07^{\circ} \pm 73.29\right)$ (Table 3$)$.

TABLE 3. - Results of Rayleigh's test and mean angle taken by lobsters recaptured presented by sex and size categories (in bold significant $P$ value).

\begin{tabular}{|c|c|c|c|c|}
\hline & $\mathrm{r}$ & Z & $P$ & Mean angle \\
\hline total females & 0.1762 & 4.8451 & $<0.01$ & $207.71 \pm 73.54$ \\
\hline $\begin{array}{l}\text { total males } \\
\text { size groups }\end{array}$ & 0.1348 & 4.2168 & $<0.02$ & $224.58 \pm 75.36$ \\
\hline total small & 0.2592 & 6.408 & $<0.002$ & $235.04 \pm 72.35$ \\
\hline small females & 0.2592 & 4.7037 & $<0.05$ & $197.72 \pm 69.73$ \\
\hline small males & 0.2372 & 4.8405 & $<0.01$ & $267.68 \pm 70.76$ \\
\hline total medium & 0.1324 & 3.4572 & $<0.05$ & $187.25 \pm 75.47$ \\
\hline medium females & 0.1104 & 0.9879 & $>0.2$ & - \\
\hline medium males & 0.1817 & 3.8329 & $<0.05$ & $169.07 \pm 73.29$ \\
\hline total large (males) & 0.2843 & 2.020 & $>0.1$ & - \\
\hline
\end{tabular}



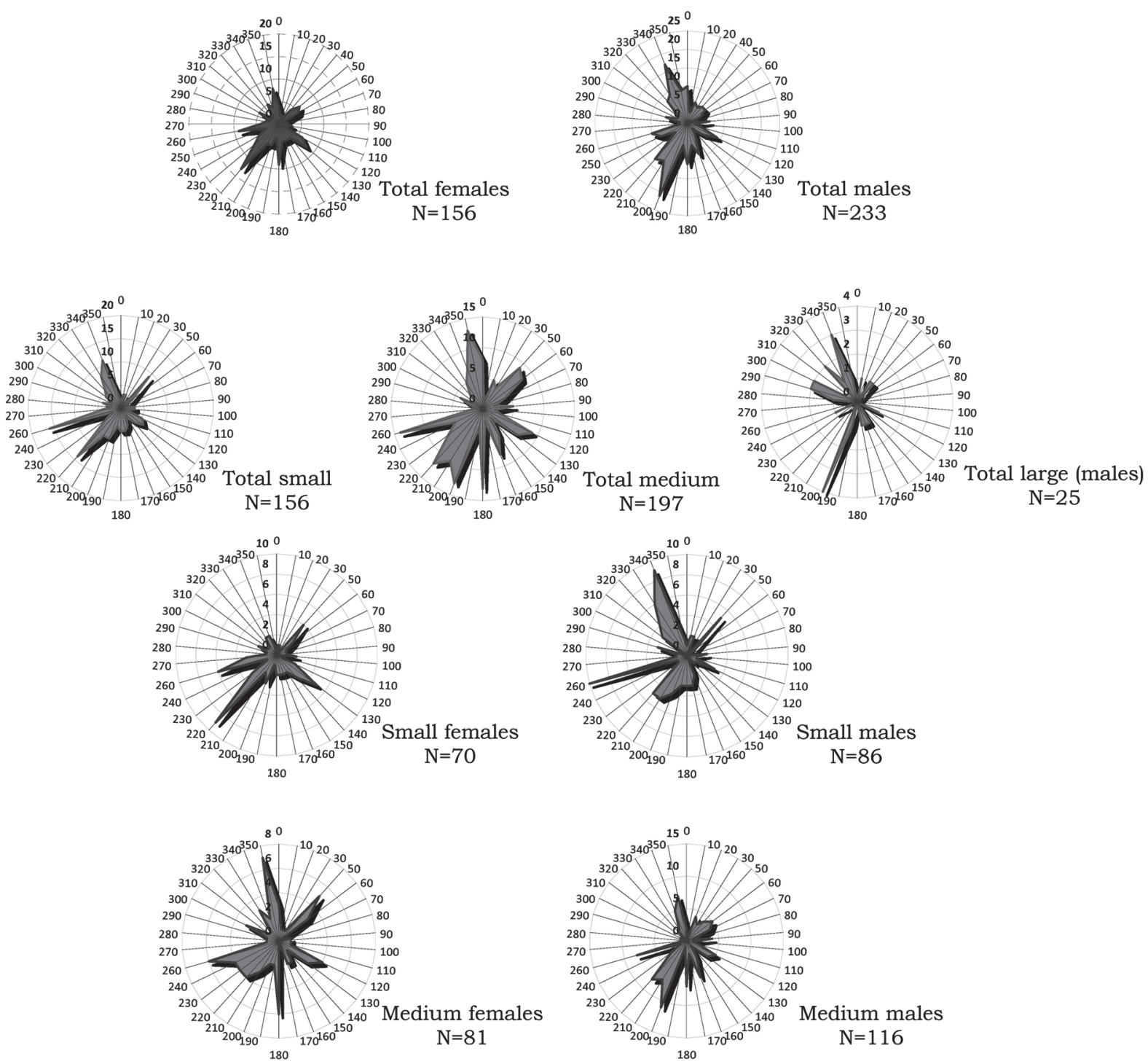

FIG. 4. - Circular distribution for lobsters recaptured presented by sex and size categories.

\section{DISCUSSION}

This study showed a high site fidelity and limited movements in tagged P. elephas. Of the lobsters, $60.4 \%$ moved a distance of less than $2 \mathrm{~km}$ from the centre of the protected area (site of release), a distance shorter than the arbitrary value of $5 \mathrm{~km}$ chosen by Booth (1997) to define large-scale movement. Movement patterns of lobsters resulted in the exchange of individuals between the protected area and nearby harvested areas even in the first year of experimentation (Follesa et al., 2007). Considering that the mean distance moved by lobsters in a year was $c a .2 \mathrm{~km} / \mathrm{yr}$ and that the maximum distance a lobster would have to cover in order to move outside the area would be between 1.4 and $1.6 \mathrm{~km}$ (straight line), it appears clear that a spillover of individuals outside the area would be possible after the first year of tagging.

In general, there did not seem to be a clear relationship between lobster movement pattern and lobster sex or size. However, a more uniform circular distribution was noted in the largest individuals: males in the large size group and females in the medium size group. Longer distances were travelled by sexually immature males (CL 54.6-79.9) and females (CL 57-79.9). Similar size-related characteristics of movement by immature individuals have also been reported for other spiny lobster species, including P. cygnus (Phillips, 1983), P. argus (Davis 
and Dodrill, 1989), P. gilchristi (Groeneveld and Branch, 2002), P. delagoae (Cockcroft et al. 1995, Groeneveld, 2002), and Jasus edwardsii (McKoy, 1983; Annala and Bycroft, 1993). The progressive percentage increase of $P$. elephas biomass values recorded from 1997 to 2007 inside the protected area (Follesa et al., 2008) could be caused by a greater movement of immature individuals from inside the protected area to outside, whereas the males in the large size group and the females in the medium size group may be more sedentary. The results for size-related movements were somewhat difficult to interpret, but it could be hypothesised that mature and/or adult lobsters tended to be more resident, contributing to the rebuilding of the biomass of local lobsters. Males with CL $>110 \mathrm{~mm}$ showed the highest site association; female site fidelity tended to increase as individuals reached mature size (size at onset maturity $=76.5 \mathrm{CL}$ mm; Goñi et al., 2003). If we consider that in an unfished population the size of breeding females of $P$. elephas that contributes most to egg production is CL 105-110 mm (Goñi et al., 2003), the high fidelity by the largest females that we observed could support a greater egg production within the protected area.

It is unclear why most lobsters moved specifically in the southwest direction. Broadly speaking, the highest proportion of recaptures may occur where fishing effort is greatest even if the animals disperse randomly, resulting in an apparent directionality of dispersion that does not actually exist (Annala and Bycroft, 1993). This did not seem to happen in our study. The fishing effort was relatively evenly spread around the protected area and its distribution would probably not bias the location of the tag returns. It is likelier that the increased availability of shelters and food observed by ROV images contributed to the preferential southwest movement of juveniles and adults.

Generally, very little is known about the specific cause of directional migrations taken by spiny lobsters. Lobsters mainly wander to forage for food or to seek new individual shelters as their life styles change with growth, particularly in the juvenile phase (Norman et al.,1994). Following each moult and growth increment, the progressively larger juvenile searches for and finds larger, suitably-sized holes or crevices for protection during foraging (George, 2005). Herrnkind (1980) stated that adults sometimes move seasonally for moulting and reproductive purposes or episodically to avoid short-term adverse envi- ronmental conditions, but they often return to their original area. Although very few data of the initial capture location were available, no particular ability of lobsters to find the way back to their home patch and no correlation between homing ability and sex or size were found during our study. It did not seem that the greatest sedentary behaviour of the largest males and females could be explained by a particular ability to orientate to their patch within the reserve.

As in some other lobster studies (Kelly and MacDiarmid, 2003), we found no evidence for a relationship between days at liberty and distance moved.

Our findings on the movement patterns of lobsters demonstrate the potential importance of no-take areas in fisheries management. The evaluation of the impact of no-take areas on a fished stock is a complex process involving factors such as the displacement of fishing effort from no-take areas to open areas, the dynamics of fishing fleets, and biological parameters influencing productivity (Stockhausen $e t$ al., 2000). Movement of lobsters in and out of the no-take areas can be considered to be another important factor because of its influence on stock rebuilding inside the no-take area and the spillover of individuals (Gardner et al., 2003). Our results highlight a high level of movement between the protected area and the surrounding zone, which may contribute to the increased lobster biomass at the no-take boundaries (Follesa et al. 2007, 2008). Similar patterns were found in another Mediterranean reserve. Goñi et al., 2006 found that lobster spillover from the Columbretes Marine Reserve in Spain enhanced fishery CPUE up to $4 \mathrm{~km}$ from the MPA boundary. Results from northeast New Zealand (Kelly, 2001) suggest that with $J$. edwardsii occasional spillover can occur.

Our study provides further insight into the potential effects of introducing protected areas into managed commercial spiny lobster fisheries. Although our results cannot be generalised to all protected areas, there is no doubt that in some circumstances stock moved into managed areas may not necessarily be sedentary, thus providing further benefits to the neighbouring commercial areas.

\section{REFERENCES}

Annala, J.H. and B. Bycroft. - 1993. Movements of rock lobsters (Jasus edwardsii) tagged in Fiordland, New Zealand. N. Z. J. Mar. Freshw. Res., 27: 183-190.

Attwood, C.G. and B.A. Bennett. - 1995. Modelling the effect of 
marine reserves on the recreational shore-fishery of the Southwestern Cape, South Africa. S. Afr. J. Mar. Sci., 16: 227-240.

Booth, J.D. - 1997. Long distance movement in Jasus spp. and their role in larval recruitment. Bull. Mar. Sci., 61: 111-128.

Campillo, A., L. De Reynal and J. Amadei. - 1979. Premières observations sur la reproduction de la langouste rouge Palinurus elephas Fabricius de Méditerranée. Rapp. Comm. Int. Mer Médit., 25/26: 4.

Cockcroft, A.C., J.C. Groeneveld and G.C. Cruywagen. - 1995. The influence depth, latitude and width of the continental slope on the size distribution and availability of spiny lobsters Palinurus delagoae off the east coast of south Africa. S. Afr. J. Mar. Sci., 16: $149-160$.

Davis, G.E. and J.W. Dodrill. - 1989. Recreational fishery and population dynamics of spiny lobsters, Palinurus argus, in Florida Bay, Everglades National Park, 1977- 1980. Bull. Mar. Sci., 44: 78-88.

DeMartini, E.E. - 1993. Modelling the potential of fishery reserves for a managing Pacific coral reef fishes. Fish. Bull., 91: 414-427.

Díaz, D., M. Marí, P. Abelló and M. Demestre. - 2001. Settlement and juvenile habitat of European spiny lobsters Palinurus elephas (Crustacea: Decapoda: Palinuridae) in the western Mediterranean Sea. Sci. Mar., 65: 347-356.

Dugan, J.E. and G.F. Davis. - 1993. Applications of marine refugia to coastal fisheries management. Can. J. Fish. Aquat. Sci., 50: 2029-2042.

Follesa, M.C., D. Cuccu, R. Cannas, A. Sabatini and A. Cau. - 2007. Emigration and retention of Palinurus elephas (Fabricius, 1787) restocked in a region of the central western Mediterranean. Sci. Mar., 71(2): 279-285.

Follesa, M.C., D. Cuccu, R. Cannas, S. Cabiddu, M. Murenu, A. Sabatini and A. Cau. - 2008. Effects of protection on spiny lobster abundance and size (Palinurus elephas Fabr. 1787) in a Central Western Mediterranean Area. Hydrobiol., 606: 63-68.

Gardner, C., S. Frusher, M. Haddon and C. Buxton. - 2003. Movements of the southern rock lobster Jasus edwardsii in Tasmania, Australia. Bull. Mar. Sci., 73(3): 653-671.

George, R.W. - 2005. Evolution of life cycles, including migration, in spiny lobsters (Palinuridae) 2005. N. Z. J. Mar. Freshw. Res., 39: 503-514.

Giacalone, V.M., G. D’Anna, C. Pipitone and F. Badalamenti. - 2006. Movements and residence time of the spiny lobsters, Palinurus elephas released in a marine protected area: an investigation by ultrasonic telemetry. J. Mar. Biol. Ass. U.K., 86: 1101-1106.

Goñi, R. and D. Latrouite. - 2005. Review of the biology, ecology and fisheries of Palinurus species of European waters: Palinurus elephas (Fabricius, 1787) and Palinurus mauritanicus (Gruvel, 1911). Cah. Biol. Mar. 46: 127-142.

Goñi, R., A. Quetglas and O. Reñones. - 2003. Size at maturity, fecundity and reproductive potential of a protected population of the spiny lobster Palinurus elephas (Fabricius, 1787) from the western Mediterranean. Mar. Biol., 143: 583-592.

Goñi, R., A. Quetglas and O. Reñones. - 2006. Spillover of spiny lobsters Palinurus elephas from a marine reserve to as adjoining fishery. Mar. Ecol. Progr. Ser., 308: 207-219.

Groeneveld, J.C. - 2002. Long distance migration of the rock lobster Palinurus delagoae off South African. S. Afr. J. Mar. Sci., 24: 395-400.

Groeneveld, J.C. and G.M. Branch. - 2002. Long-distance migration of south African deep-wares rock lobster Palinurus gilchristi. Mar. Ecol. Progr. Ser., 232: 225-238.

Guenette, S., T. Lauck and C. Clark. - 1998. Marine reserve: from Beverton and Holt to the present. Rev. Fish. Biol. Fish., 8: 251-272.

Guenette, S. and T.J. Pitcher. - 1999. An age-structured model showing the benefits of marine reserves in controlling overexploitation. Fish. Res., 39: 295-303.

Herrnkind, W.F. - 1980. Spiny lobsters: patterns of movement. In: J.S. Cobb and B. Phillips (eds.), The biology and management of lobsters, Vol. 1, pp. 49-407. Physiology and behaviour. Aca- demic Press, New York.

Herrnkind, W.F. - 1983. Movement patterns and orientation. In: F.J. Wernberg and W.B. Wernberg (eds.), The biology of Crustacea. Vol. 7, pp. 41-105. Academic Press, New York.

Hunter, E., S.E. Shackley and D.B. Bennet. - 1996. Recent studies on the crawfish Palinurus elephas in South Wales and Cornwall. J. Mar. Biol. Ass. U.K., 76: 963-983.

Kelly, S. - 2001. Temporal variation in the movement of the spiny lobster Jasus edwardsii. Mar. Fresh. Res., 10: 209-231.

Kelly, S., D. Scott and A.B. MacDiarmid. - 2002. The value of a spillover fishery for spiny lobsters around a marine reserve in Northern New Zealand. Coast. Manag., 30: 153-166.

Kelly, S. and A.B. MacDiarmid. - 2003. Movements patterns of mature spiny lobsters, Jasus edwardsii, from a marine reserve. N.Z. J. Mar. Freshw. Res., 37: 149-158.

McKoy, J.L. - 1983. Movements of rock lobsters, Jasus edwardsii (Decapoda: Palinuridae), tagged near Stewart Island, New Zealand. N.Z. J. Mar. Freshw. Res., 17:357-366.

McGarvey, R. - 2004. Estimating the emigration rate of fish stocks from marine sanctuaries using tag-recovery data. Fish. Bull., 102: 464-472.

Mercer, J.P. - 1973. Studies on the spiny lobsters (Crustacea: Decapoda: Palinuridae) of the west coast of Ireland, with particular reference to Palinurus elephas Fabricius, 1787. Ph. D. thesis, Univ. College Galway, Ireland.

Norman, C.P., H. Yamakawa and T. Yoshimura. - 1994. Habitat selection, growth rate and density of juvenile Palinurus japonicus (Von Siebold, 1824) (Decapoda, Palinuridae) at Banda, Chiba Prefecture, Japan. Crustaceana, 66(3): 366-383.

Pérès, J.M.and J. Picard. - 1964. Nouveau manuel de bionomie benthique de la Méditerranée. Rec. Trav. Sta. Mar. Endoume, 31(47): 1-37.

Phillips, B.F. - 1983. Migrations of pre-adults western rock lobsters, Palinurus cygnus, in Western Australia. Mar. Biol., 76: 311-318.

Phillips, B.F. and J. Kittaka. - 2000. Spiny lobsters: fisheries and culture. Fishing News Books, Oxford.

Polacheck, T. - 1990. Year around closed areas as a management tool. Natur. Res. Model., 4: 327-354.

Rakitin, A. and D.L. Kramer. - 1996. Effect of marine reserve on the distribution of coral reef fishes in Barbados. Mar. Ecol. Prog. Ser., 131: 97-113.

Roberts, C.M. and N.V.C. Polunin. - 1993. Effects of marine reserve protection on Northern Red Sea fish populations. Proc. $7^{\text {th }}$ Int. Coral Reef Symp., 2: 979-987.

Rowe, S. - 2001. Movement and harvesting mortality of American lobsters (Homarus americanus) tagged inside and outside notake reserves in Bonavista Bay, Newfoundland. Can. J. Fish. Aquat. Sci., 58: 1336-1346.

Sanchez Lisazo, J.L., R. Goñi, O. Reñones, J.A. Garcia Charton, R. Galzin, J.T. Bayle, P. Sanchez Jerez, A. Perez Ruzafa and A.A. Ramos. - 2000. Density dependence in marine protected populations: a review. Env. Conserv., 27(2): 144-158.

Secci, E., D. Cuccu, M.C. Follesa and A. Cau. - 1999. Fishery and tagging of Palinurus elephas in Sardinian seas. In: J.C. VonVaupel Klein and F.R. Schram (eds.), The Biodiversity Crisis and Crustacea: Procedings of the Fourth International Crustacean Congress, Amsterdam. Brill, Leiden.

Stewart, J. and S.J. Kennelly. - 1998. Contrasting movements of two exploited Scyllarid lobsters of the genus Ibacus off the east coast of Australia. Fish. Res., 36: 127-132.

Stockhausen, W.T., R.N. Lipcius and B.M. Hickey. - 2000. Joint effects of larval dispersal, population regulation, marine reserve design, and exploitation on production and recruitment in the Caribbean spiny lobster. Bull. Mar. Sci., 66: 957-990.

Zar, J.H. - 1996. Biostatistical analysis. $3^{\text {rd }}$ edition. Prentice-Hall. Englewood Cliffs-NJ.

Scient. ed.: P. Abelló.

Received July 7, 2008. Accepted November 26, 2008.

Published online April 14, 2009. 